\title{
PENGUASAAN RANGKAIAN TES KEBUGARAN JASMANI INDONESIA (TKJI) MELALUI DISKUSI DAN SIMULASI \\ (Kajian Pustaka Pemahaman Teori dan Praktek TKJI Terhadap \\ Mahasiswa PGSD UMTAS)
}

\author{
Rahmat Permana \\ Universitas Muhammadiyah Tasikmalya \\ rahmatumtas@gmail.com
}

\begin{abstract}
Elementary School teachers at primary school level are groomed to become classroom teachers in science subjects, social studies, Indonesian Language, Civic Education and mathematics. While the position is beyond the fifth lesson Physical Education such subjects, but field data show that some elementary school gym teacher shortage this have an impact on classroom teachers forced to teaching phsical Education. If this happens then certainly the goal of learning the sport in elementary school will not be achieved. The writer tries to optimize the ability of students elementary teacher education on a series of physical fitness tests Indonesia. Because these tests are the basis for a sports teacher to determine the level of physical fitness in children. By knowing these tests students are expected to teach at the elementary level sport elementary school age children if the situation in the school is no physical eduction teacher. The series of tests consisting of 1. Running 30 meters, 2. Pull Up, 3. Sit Up, 4. Skip Upright, 5. Running 600 meters. The fifth series of tests has had a physical fitness test norm Indonesia that has been set by the experts of physical education, the author only do in-depth understanding to the students through the study of five discussion meetings and perform simulation test as much as two meetings.

Keywords: Physical Fitness Test Indonesia (TKJI), Study Discussion, Simulation Tests.
\end{abstract}

Program studi PGSD merupakan pencetak guru pada tingkat Sekolah Dasar yang dipersiapkan untuk menjadi guru kelas pada mata pelajaran IPA, IPS, B.Indonesia Pendidikan Kewarganegaraan dan matematika. Sedangkan posisi pelajaran PJOK berada diluar kelima mata pelajaran tersebut, akan tetapi data dilapangan menunjukan bahwa beberapa Sekolah Dasar kekurangan guru olahraga hal ini berdampak pada guru kelas yang dipaksakan untuk meengajar olahraga. Apabila ini terjadi maka dipastikan tujuan pembelajaran olahraga di SD tidak akan tercapai. Maka penulis mencoba untuk mengoptimalkan kemampuan mahasiswa PGSD pada rangkaian tes kebugaran jasmani Indonesia. Karena tes ini merupakan dasar bagi seorang pengajar olahraga untuk mengetahui tingkat kesegaran jasmani pada anak. Pemahaman tes ini diharapkan mahasiswa dapat mengajar olahraga level dasar pada anak usia SD apabila situasi dan kondisi di sekolah tidak ada guru olahraga. Adapun rangkaian tes terdiri dari 1. Lari 30 meter, 2. Pull Up, 3. Sit Up, 4. Loncat Tegak, 5. Lari 600 meter. Kelima rangkaian tes telah memiliki norma tes kesegaran jasmani indonesia yang telah ditetapkan oleh para ahli pendidikan jasmani, penulis hanya melakukan pemahaman kepada mahasiswa secara mendalam melalui kajian diskusi lima pertemuan dan melakukan simulasi tes sebanyak dua pertemuan.

Kata kunci : Tes Kebugaran Jasmani Indonesi (TKJI), Kajian Diskusi, Simulasi Tes. 


\section{PENDAHULUAN}

Persebaran guru di Indonesia tidak merata, di satu sisi kelebihan guru tetapi di sisi lain Indonesia kekurangan guru pendidikan jasmani dan kesehatan (Penjaskes). Indonesia membutuhkan guru Penjaskes di SD mencapai 54 ribu orang. Dilansir oleh Dirjen Pendidikan Dasar Kemendikbud Hamid Muhammad (2014) mengatakan kekurangan ini tidak bisa dibiarkan. Tujuan pendidikan di SD untuk membentuk siswa yang berkarakter, sehat, dan menjalankan perilaku hidup bersih akan mudah dicapai jika jumlah guru Penjaskes mencukupi. Proses rekrutmen CPNS guru yang saat ini sedang berlangsung diharapkan dapat memenuhi kebutuhan guru Penjaskes secara bertahap. Selain itu Kemendikbud juga meminta perguruan tinggi untuk mencetak calon guru Penjaskes yang berkualitas.

Dari data Kemendikbud, jumlah guru SD secara nasional menunjukkan jumlah yang berlebih. Jumlah guru SD di Indonesia mencapai hampir 1,6 juta orang. Namun, 519 ribu orang diantaranya adalah guru tidak tetap (GTT) atau honorer. Hasil pemetaan Kemendikbud, ada empat masalah utama terkait pendidik. Masalah itu antara lain; distribusi yang belum merata, kualitas pedagogik, guru mengajar tidak sesuai kompetensi, dan urusan kesejahteraan

Mahasiswa PGSD merupakan calon guru kelas pada jenjang Sekolah Dasar yang mempunyai penguasaan bidang studi dalam mata pelajaran SD meliputi PKn, IPS, IPA, Matematika, dan Bahasa Indonesia. Sedangkan pendidikan jasmani dan olahraga berada pada mata pelajaran yang diajar oleh lulusan mahasiswa PGSD PENJAS, maka tentu saja lulusan PGSD tidak bisa mengajar PENJAS. Pernyataan di atas tidak sesuai fakta dilapangan sebagai contoh bersumber dari harian times Indonesia $\begin{array}{llll}\text { tanggal } & 25 & \text { Februari } & 2016\end{array}$ :"Kabupaten Blitar terjadi kekurangan 1000 lebih guru olahraga. Kekurangan itu terjadi pada tingkat Sekolah Dasar (SD). Tentu saja kekurangan guru kelas ini cukup mengganggu proses kegiatan belajar mengajar". kalimantan ada Sekolah Dasar yang sudah 10 tahun tidak mempunyai guru olahraga.

Guru kelas apabila dibebani tugas mengajar olahraga tentu saja tidak akan berdampak maksimal pada hasil pembelajaran dikarenakan dalam perkuliahan program studi PGSD tidak ada mata kuliah perencanaan, pelaksanaan dan praktek mengajar olahraga. Sebab dalam kompetensi guru harus memiliki empat bidang kompetensi yaitu pedagogik, profesional, sosial dan kpribadian.

Tim Direktorat Profesi Pendidik Dirjen Peningkatan Mutu Pendidik dan Tenaga Kependidikan (2008): “Kompetensi Pedagogik adalah kemampuan pemahaman terhadap peserta didik, perancangan dan pelaksanaan pembelajaran, evaluasi hasil belajar, dan pengembangan peserta didik untuk mengaktualisasikan berbagai potensi yang dimilikinya". Kompetensi Profesional adalah penguasaan materi pembelajaran secara luas dan mendalam, yang mencakup penguasaan materi kurikulum mata pelajaran di sekolah dan substansi keilmuan yang menaungi materinya, serta penguasaan terhadap struktur dan metodologi keilmuannya. Kompetensi Sosial adalah kemampuan guru untuk berkomunikasi dan bergaul secara efektif dengan peserta didik, tenaga kependidikan, orang tua/wali peserta didik, dan masyarakat sekitar. Kompetensi Kepribadian adalah kemampuan personal yang mencerminkan kepribadian yang mantap, stabil, dewasa, arif dan berwibawa, menjadi teladan bagi peserta didik, dan berakhlak mulia. Lebih lanjut Menurut Koentjaraningrat (1994:26) "Kepribadian adalah beberapa ciri watak yang diperlihatkan seseorang secara lahir, konsisten, dan konsukuen".

Salah satu kemampuan yang harus dimilki guru ialah kompetensi pedagogik apabila mengajar olahraga maka muncul permasalahan apakah guru kelas SD mempunyai pemahaman, perancangan dan pelaksanaan mata pelajaran olahraga. Maka 
dengan dinamika ini setidaknya pemahaman tentang dasar tes kesegaran jasmani yang sering dilakukan pada rentang usia SD yaitu tes kebugaran Jasmani Indonesia (TKJI) kepada mahasiswa PGSD UMTAS, mereka adalah calon guru kelas sekaligus pada saat atau situasi tertentu akan mengajar olahraga maka tidak diragukan lagi kemampuan mereka dalam melaksanakan pelajaran olahraga.

Tes kesegaran jasmani indonesia termasuk ke dalam tes untuk mengukur kebugaran jasmani anak dan remaja, penulis berasumsi bahwa pemahaman tes ini perlu diberikan kepada mahasiswa calon guru SD karena melihat dilema pembelajaran olahraga di sekolah dasar ketiadaan sumber daya manusia khususnya sarjana olahraga di SD maka guru seorang guru kelas harus paham dari segi teoritis maupun segi prakteknya. Apabila setelah paham tentang TKJI di harapkan pula di masa yang akan datang mahasiswa PGSD dapat mempraktekannya kepada peserta didik SD untuk mengetahui tingkat kebugaran jasmaninya.

Minimnya pemahaman secara teori maupun praktek mahasiswa PGSD terhadap pelaksanaan rangkain tes kebugaran jasmani indonesia (TKJI) khususnya dalam kelompok umur SD membuat kondisi pengajaran olahraga tidak sesuai ketika seorang guru SD sama sekali tidak mengetahui tentang rangkaian TKJI, sesuai dengan fenomena di lapangan bahwa di sekolah dasar sangat kekurangan guru olahraga hal ini mengakibatkan guru kelas terpaksa mengajar olahraga.

Dari uraian di atas dapat disimpulkan bahwa upaya apa yang bisa dilakukan untuk mahasiswa PGSD sebagai calon guru kelas tetapi dalam situasi atau kondisi tertentu bila diberi tanggung jawab untuk mengajar olahraga maka mereka harus siap. Untuk itu perlu dilakukan upaya pemahaman TKJI melalui kajian diskusi dan simulasi.

Tujuan kajian konsep ini adalah untuk memberikan pemahaman tentang rangkaian tes kebugaran jasmani indonesia yang terdiri dari lima rangkaian tes melalui kajian diskusi untuk pemahaman teori dan simulasi untuk mematangkan proses pelaksanaan. Kelima rangkaian tes itu ialah lari sprint, pull up, sit up, vertical jump, lari jarak sedang.

Dengan adanya kajian ini diharapkan dapat memberikan manfaat bagi mahasiswa PGSD dan bagi dosen pengampu mata kuliah pendidikan jasmani dan olahraga yaitu :

1. Secara teoritis dapat menyumbangkan keilmuan dalam pengembangan didaktik metodik dalam pengajaran PENJAS dan Olahraga, baik bagi dosen penjas maupun mahasiswa yang mengambil PRODI PGSD.

2. kajian ini bermanfaat bagi mahasiswa PGSD yang mengalami kesulitan untuk melaksanakan praktek tes kebugaran pada siswa-siswi SD.

3. Mendapatkan variasi strategi pembelajaran penjas bagi dosen pengampu mata kuliah pendidikan jasmani dan olahraga di FKIP UMTAS.

4. Bagi penulis selanjutnya dapat digunakan sebagai rujukan mengenai pemahaman rangkaian tes kebugaran jasmani indonesia untuk siswa SD untuk menyempurnakan.

5. Bagi guru SD dapat dijadikan sebagai rujukan apabila bermaksud ingin mengetahui tingkat kebugaran siswa SD

\section{METODE DISKUSI}

Metode diskusi mendorong siswa untuk berdialog dan bertukar pendapat, dengan tujuan agar siswa dapat terdorong untuk berpartisipasi secara optimal, tanpa ada aturan-aturan yang terlalu keras, namun tetap harus mengikuti etika yang disepakati bersama. Metode diskusi adalah cara memecahkan masalah yang dipelajari melalui urun pendapat dalam diskusi kelompok. Moh. Uzer Usman (2005:94), "menyatakan bahwa diskusi kelompok adalah proses yang teratur yang melibatkan sekelompok orang di wajah informal untuk menghadapi interaksi dengan berbagai pengalaman atau informasi, 
kesimpulan atau solusi untuk masalah" Dalam pembelajaran dengan metode diskusi ini makin lebih memberi peluang pada siswa untuk terlibat secara aktif dalam pembelajaran walaupun guru masih menjadi kendali utama.

Diskusi dapat dilaksanakan dalam dua bentuk yaitu : diskusi kelompok kecil (small group discussion) dengan kegiatan kelompok kecil dan diskusi kelas, yang melibatkan semua siswa di dalam kelas, baik dipimpin langsung oleh gurunya atau dilaksanakan oleh seorang atau beberapa pemimpin diskusi yang dipilih langsung oleh siswa dengan tujuan untuk memberikan motivasi kepada siswa agar dapat berkomunikasi secara lisan, memberikan kesempatan kepada peserta didik untuk menggunakan pengetahuan dan informasi yang telah dimiliki dan mengembangkan sikap saling hormat menghormati dan tenggang rasa terhadap keragaman pendapat orang lain, dalam rangka mengembangkan kecerdasan interpersonal siswa. lebih lanjut Moh. Surya (1988:107), "Mendefinisikan diskusi kelompok adalah proses di mana siswa akan mendapatkan kesempatan untuk berkontribusi pengalaman mereka sendiri dalam memecahkan masalah umum". Dalam diskusi ini tertanam juga tanggung jawab dan harga diri.

Dalam kajian ini diskusi dilakukan selam lima pertemuan sesuai dengan jumlah rangkaian tes kebugaran jasmani, maka penulis membagi ke dalam lima kelompok untuk mendiskusikan bagaimana tujuan dan tata laksana dalam menjalankan tes kebugaran jasmani Indonesia.

Dengan berjalanya diskusi mengenai rangkaian tes ini mahasiswa PGSD diharapkan mampu memahami secara teori apa saja kegunaan tiap-tiap tes pada TKJI. Kajian ini merupakan konsep tindakan kelas maka asumsi di bawah ini merupakan asumsi-asumsi tindakan yang dilakukan oleh penulis yaitu :

1. Pemahaman lewat kajian diskusi akan lebih mengoptimalkan kemampuan mahasiswa secara teoritis terhadap tes kebugaran jasmani Indonesia. Menurut
Subroto (2002: 185) ada beberapa keuntungan dan kelemahan metode diskusi antara lain sebagai berikut:

Keuntungan metode diskusi

a. Metode diskusi melibatkan siswa secara langsung dalam proses belajar.

b. Setiap siswa dapat menguji pengetahuan dan penguasaan bahan pelajarannya masing-masing.

c. Metode diskusi dapat menumbuh dan mengembangkan cara berpikir dan sikap ilmiah.

d. Dengan mengajukan dan mempertahankan pendapatnya dalam diskusi diharapkan para siswa akan dapat memperoleh kepercayaan akan (kemampuan) diri sendiri.

e. Metode diskusi dapat menunjang usahausaha pengembangan sikap sosial dan sikap demokratis para siswa

Lebih lanjut kelebihan Metode Diskusi :

a. Menyadarkan anak didik bahwa masalah dapat dipecahkan dengan berbagai jalan dan bukan satu jalan.

b. Menyadarkan anak didik bahwa dengan berdiskusi mereka saling mengemukakan pendapat secara konstruktif sehingga dapat diperoleh keputusan yang lebih baik.

c. Membiasakan anak didik untuk mendengarkan pendapat orang lain sekalipun berbeda dengan pendapatnya sendiri dan membiasakan bersikap toleransi (Syaful Bahri Djamarah, 2000)

\section{METODE SIMULASI}

Simulasi berasal dari kata simulate yang artinya berpura-pura atau berbuat seakan-akan. Sebagai metode mengajar, simulasi dapat diartikan cara penyajian pengalaman belajar dengan menggunakan situasi tiruan untuk memahami tentang konsep, prinsip, atau keterampilan tertentu. Model pembelajaran simulasi merupakan model pembelajaran yang membuat suatu peniruan terhadap sesuatu yang nyata, terhadap keadaan sekelilingnya (state of affaris) atau proses. Model pembelajaran ini dirancang untuk membantu siswa mengalami

\section{Jurnal Refleksi Edukatika}

Vol. 6 No. 2 Juni 2016 
bermacam-macam proses dan kenyataan sosial dan untuk menguji reaksi mereka, serta untuk memperoleh konsep keterampilan pembuatan keputusan.

Model pembelajaran ini diterapkan didalam dunia pendidikan dengan tujuan mengaktifkan kemampuan yang dianalogikan dengan proses sibernetika. Pendekatan simulasi dirancang agar mendekati kenyataan dimana gerakan yang dianggap kompleks sengaja dikontrol, misalnya, dalam proses simulasi ini dilakukan dengan menggunakan simulator.

Metode simulasi merupakan salah satu metode mengajar yang dapat digunakan dalam pembelajaran kelompok. Proses pembelajaran yang menggunakan simulasi cenderung objeknya bukan benda atau kegiatan yang sebenarnya, melainkan kegiatan mengajar yang bersifat pura-pura. Kegiatan simulasi dapat dilakukan oleh siswa pada kelas tinggi di Sekolah Dasar. Dalam pembelajaran, siswa akan dibina kemampuannya berkaitan dengan keterampilan berinteraksi dan berkomunikasi dalam kelompok. Disamping itu, dalam metode simulasi siswa diajak untuk bermain peran beberapa perilaku yang dianggap sesuai dengan tujuan pembelajaran.

Ada beberapa jenis model simulasi di antaranya, yaitu:

1. Bermain peran (role playing)

Dalam proses pembelajarannya metode ini mengutamakan pola permainan dalam bentuk dramatisasi. Dramatisasi dilakukan oleh kelompok siswa dengan mekanisme pelaksanaan yang diarahkan oleh guru untuk melaksanakan kegiatan yang telah ditentukan atau direncanakan sebelumnya. Simulasi ini lebih menitik beratkan pada tujuan untuk mengingat atau menciptakan kembali gambaran masa silam yang memungkinkan terjadi pada masa yang akan datang atau peristiwa yang aktual dan bermakna bagi kehidupan sekarang.

2. Sosiodrama

Dalam pembelajarannya yang dilakukan oleh kelompok untuk melakukan aktivitas belajar memecahkan masalah yang berhubungan dengan masalah individu sebagai makhluk sosial. Misalnya, hubungan anak dan orangtua, antara siswa dengan teman kelompoknya.

3. Permainan simulasi (Simulasi games)

Dalam pembelajarannya siswa bermain peran sesuai dengan peran yang ditugaskan sebagai balajar membuat suatu keputusan.

Dari uraian di atas ada tiga macam teknik simulasi sedangkan dalam peneilitian ini penulis mengambil teknil Simulasi Games karena berdasarkan variabel terikat penelitian tentang praktek tes kebugaran jasmani maka mahasiswa diberi peran sesuai penugasan dari dosen yaitu dua peran satu sebagian sebagai tester dan lainya sebagai sampel tes.

Lebih lanjut pemahaman dengan simulasi tes akan lebih memaksimalkan mahasiswa dalam perencanaan, pelaksanaan dan prosedur penilaian dalam tes kebugaran jasmani indonesia. Sri Anitah, W. (2007: 5.22) metode simulasi merupakan salah satu metode pembelajaran yang dapat digunakan dalam pembelajaran kelompok. Proses pembelajaran yang menggunakan metode simulasi cenderung objeknya bukan benda atau kegiatan yang sebenarnya, melainkan kegiatan mengajar yang bersifat pura-pura. Kegiatan simulasi dapat dilakukan oleh siswa pada kelas tinggi di sekolah dasar.

\section{PEMBAHASAN}

\section{Pelaksanaan TKJI melalui Diskusi dan Simulasi}

Tes Kesegaran Jasmani Indonesia (TKJI) adalah suatu tolak ukur untuk mengukur tingkat kesegaran jasmani yang berbentuk rangkaian butir-butir tes yang menjadi salah satu tolak ukur dalam mengetahui tingkat kesegaran jasmani anak yang digolongkan sesuai dengan umur anak tersebut. Tes kesegaran jasmani indonesia atau yang biasa disebut dengan tkji terbagi dalam 4 golongan instrumen tes yang dibedakan sesuai dengan golongan umur yaitu: 1) tes kesegaran jasmani indonesia (TKJI) usia 6-9 tahun, 2) tes 
kesegaran jasmani indonesia (tkji) 10-12 tahun dan, 3) tes kesegaran jasmani indonesia (TKJI) usia 13-15 tahun, 3) tes kesegaran jasmani indonesia (TKJI) usia 16-19 tahun. Sesuai dengan tolak ukur kesegaran jasmani, maka tolak ukur ini hanya berlaku untuk mengukur kesegaran jasmani anak sesuai dengan golongan umur tersebut. Dengan demikian tolak ukur ini tidak berlaku untuk mengukur kesegaran jasmani bagi mereka yang tidak termasuk kelompok umur tersebut.

Pusat kebugaran jasmani dan rekreasi menyusun rangkaian tes yang diberi nama tes kebugaran jasmani indonesia (TKJI) yang kategorinya dikelompokan menjadi empat kelompok
- Umur 6 s/d 9 tahun

- Umur $10 \mathrm{~s} / \mathrm{d} 12$ tahun

- Umur 13 s/d 15 tahun

- Umur 16 s/d 19 tahun

Kategori dengan membedakan juga jenis kelamin dimana kategori putra dan putri. TKJI merupakan battery test dalam metode diskusi dan simulasi sampel diberikan materi sebagai berikut :

1. Sprint

Sprint atau lari cepat bertujuan untuk mengukur kecepatan. Kategori jarak yang harus ditempuh oleh masing-masing kelompok umur berbeda. Jarak tempuh sprint dapat dilihat pada tabel di bawah ini:

Tabel 1

Jarak Tempuh Tes Lari cepat

(Nurhasan,2013:64)

\begin{tabular}{|c|c|c|c|}
\hline \multirow{2}{*}{ Kelompok umur } & \multicolumn{2}{|c|}{ Jarak } & \multirow{2}{*}{ Keterangan } \\
\hline & Putra & Putri & \\
\hline $6 \mathrm{~s} / \mathrm{d} 9$ tahun & 30 meter & 30 meter & \multirow{4}{*}{$\begin{array}{l}\text { Pencatatan waktu dilakukan } \\
\text { dalam satuan detik dengan } \\
\text { satu angka dibelakang } \\
\text { koma. }\end{array}$} \\
\hline $10 \mathrm{~s} / \mathrm{d} 12$ tahun & 40 meter & 40 meter & \\
\hline $13 \mathrm{~s} / \mathrm{d} 15$ tahun & 50 meter & 50 meter & \\
\hline $16 \mathrm{~s} / \mathrm{d} 19$ tahun & 60 meter & 60 meter & \\
\hline
\end{tabular}

Tabel 1.2

Norma Penilaian Tes Lari cepat

(Nurhasan,2013:65)

Sedangkan penilaian tesnya adalah:

\begin{tabular}{|c|c|c|c|c|}
\hline \multicolumn{2}{|c|}{ Usia $6 \mathrm{~s} / \mathrm{d} 9$ tahun } & \multirow{2}{*}{ Nilai } & \multicolumn{2}{|c|}{ Usia $10 \mathrm{~s} / \mathrm{d} 12$ tahun } \\
\cline { 5 - 5 } \cline { 5 - 5 } Putra & Putri & & Putra & Putri \\
\hline Sd -5.5 detik & Sd -5.8 detik & 5 & Sd- 6.3 detik & Sd - 6.7 detik \\
\hline $5.6-6.1$ detik & $5.9-6.6$ detik & 4 & $6.4-6.9$ detik & $6.8-7.5$ detik \\
\hline $6.2-6.9$ detik & $6.7-7.8$ detik & 3 & $7.0-7.7$ detik & $7.6-8.3$ detik \\
\hline $7.0-8.6$ detik & $7.9-9.2$ detik & 2 & $7.8-8.8$ detik & $8.4-9.6$ detik \\
\hline 8.7 - dst & $9.3-$ dst & 1 & $8.9-$ dst & $9.7-$ dst \\
\hline
\end{tabular}




\begin{tabular}{|c|c|c|c|c|}
\hline \multicolumn{2}{|c|}{ Usia 13-16 tahun } & \multirow{2}{*}{ Nilai } & \multicolumn{2}{|c|}{ Usia 17-19 tahun } \\
\cline { 5 - 5 } & Putra & & Putra & Putri \\
\hline Sd -6.7 detik & Sd -7.7 detik & 5 & Sd - 7.2 detik & Sd-8.4 detik \\
\hline $6.8-7.6$ detik & $7.8-8.7$ detik & 4 & $7.3-8.3$ detik & $8.5-9.8$ detik \\
\hline $7.7-8.7$ detik & $8.8-9.9$ detik & 3 & $8.4-9.6$ detik & $9.9-11.4$ detik \\
\hline $8.8-10.3$ detik & $\begin{array}{c}10.9-11.9 \\
\text { detik }\end{array}$ & 2 & $9.7-11.0$ detik & $\begin{array}{c}11.5-13.4 \\
\text { detik }\end{array}$ \\
\hline $10.4-$ dst & $12.0-$ dst & 1 & $11.1-$ dst & $13.5-$ dst \\
\hline
\end{tabular}

2. Pull-up

Pull-up bertujuan untuk mengukur kekuatan otot lengan dan bahu. Untuk penilaian kelompok umur 06 - 09 tahun dan umur $10-12$ tahun melakukan pull-up selama
60 detik dengan penilaian. Dalam diskusi mahasiswa harus memahami betul tentang pelaksanaan tes ini. Adapun kategori tes pull up dapat dilihat pada tabel di halaman sembilan

Tabel 2

Ketegori Tes Pull Up Berdasarkan Usia dan Jenis Kelamin (Nurhasan,2013:66)

\begin{tabular}{|c|c|c|c|c}
\hline \multicolumn{2}{|c|}{ Usia 6 s/d 9 tahun } & \multirow{2}{*}{ Nilai } & \multicolumn{2}{|c}{ Usia $10 \mathrm{~s} / \mathrm{d} 12$ tahun } \\
\cline { 5 - 5 } & putra & & putra & Putri \\
\hline 40 detik ke atas & 33 detik ke atas & 55 & 51 detik ke atas & 40 detik ke atas \\
\hline $22-39$ detik & $18-32$ detik & 4 & $31-51$ detik & $20-39$ detik \\
\hline $09-21$ detik & $09-17$ detik & 3 & $15-30$ detik & $08-19$ detik \\
\hline $03-08$ detik & $03-08$ detik & 2 & $05-14$ detik & $02-07$ detik \\
\hline $00-02$ detik & $00-02$ detik & 1 & $00-04$ detik & $00-01$ detik \\
\hline
\end{tabular}

Untuk kelompok umur 13 - 15 tahun dan umur 16 - 19 tahun, melakukan gerakan pull-up selama 60 detik. Penilaian putra dihitung frekuensinya, sedangkan yang putri yang dihitung waktunya, masing-masing penilaian sebagai berikut.

\begin{tabular}{|c|c|c|c|c|}
\hline \multicolumn{2}{|c|}{ Usia $13 \mathrm{~s} / \mathrm{d} 15$ tahun } & \multirow{2}{*}{ nilai } & \multicolumn{2}{|c|}{ Usia $16 \mathrm{~s} / \mathrm{d} 19$ tahun } \\
\cline { 5 - 5 } \cline { 4 - 5 } Putra & putri & & Putra & putri \\
\hline 16 detik ke atas & 41 detik ke atas & 5 & 19 detik ke atas & 40 detik ke atas \\
\hline $11-15$ detik & $22-40$ detik & 4 & $14-18$ detik & $20-39$ detik \\
\hline $06-10$ detik & $10-21$ detik & 3 & $09-13$ detik & $08-19$ detik \\
\hline $02-05$ detik & $03-09$ detik & 2 & $05-08$ detik & $02-07$ detik \\
\hline $00-01$ detik & $00-02$ detik & 1 & $00-04$ detik & $00-02$ detik \\
\hline
\end{tabular}


3. Sit-Up bertujuan untuk mengukur kekuatan dan ketahanan otot perut. Kelompok umur 6-9 tahun dan 10-12 tahun melakukan selama 30 detik dengan kriteria penilaian tertera pada tabel tiga.

4. Vertical jump

Tes ini bertujuan untuk mengukur daya ledak otot tungkai. Ukuran papan sekala selebar $30 \mathrm{~cm}$ dan panjang $150 \mathrm{~cm}$, dimana jarak antara garis sekala satu dengan yang lainnya masingmasing $1 \mathrm{~cm}$. Papan sekala ditempelkan di tembok dengan jarak sekala nol(0) dengan lantai $150 \mathrm{~cm}$. Pertama berdiri menyamping papan sekala dengan mengangkat tangan keatas ukur tinggi yang didapat, kemudian lakukan lompatan setinggi mungkin sebanyak tiga kali, tiap lompatan dicatat tinggi yang diperoleh kemudian ambil yang terteinggi, selisih antara raihan tertinggi dengan pengukuran yang pertama saat tidak melompat adalah hasil vertical jump. Adapun kriteria penilaian tes vertical jump terdapat pada tabel empat.

Tabel 3

Kategori Tes Sit Up Berdasarkan Usia dan jenis Kelamin

(Nurhasan,2013:68)

\begin{tabular}{|c|c|c|c|c|}
\hline \multicolumn{2}{|c|}{ Usia $6 \mathrm{~s} / \mathrm{d} 9$ tahun } & \multirow{2}{*}{ nilai } & \multicolumn{2}{|c|}{ Usia $10 \mathrm{~s} / \mathrm{d} 12$ tahun } \\
\cline { 5 - 5 } putra & putri & & putra & Putri \\
\hline 7 kali ke atas & 15 kali ke atas & 5 & 23 kali ke atas & 20 kali ke atas \\
\hline $3-16$ kali & $11-14$ kali & 4 & $18-22$ kali & $14-19$ kali \\
\hline $07-12$ kali & $04-10$ kali & 3 & $12-17$ kali & $07-13$ kali \\
\hline $02-06$ kali & $02-03$ kali & 2 & $04-11$ kali & $02-06$ kali \\
\hline $00-01$ kali & $00-01$ kali & 1 & $00-03$ kali & $00-01$ kali \\
\hline
\end{tabular}

Sedangkan untuk kreteria penilaian kelompok umur 13-15 tahun dan 16-19 tahun yang melakukan selama 60 detik adalah

\begin{tabular}{|c|c|c|c|c|}
\hline \multicolumn{2}{|c|}{ Usia $13 \mathrm{~s} / \mathrm{d} 15$ tahun } & \multirow{2}{*}{ nilai } & \multicolumn{2}{|c|}{ Usia $16 \mathrm{~s} / \mathrm{d} 19$ tahun } \\
\cline { 5 - 5 } \cline { 4 - 5 } putra & Putri & & putra & Putri \\
\hline 38 kali ke atas & 28 kali ke atas & 5 & 41 kali ke atas & 29 kali ke atas \\
\hline $28-37$ kali & $19-27$ kali & 4 & $30-40$ kali & $20-28$ kali \\
\hline $19-27$ kali & $09-18$ kali & 3 & $21-29$ kali & $10-19$ kali \\
\hline $08-18$ kali & $03-08$ kali & 2 & $10-20$ kali & $03-09$ kali \\
\hline $00-07$ kali & $00-02$ kali & 1 & $00-09$ kali & $00-02$ kali \\
\hline
\end{tabular}


Tabel 4

Kategori Tes Vertical Jump Berdasarkan Usia dan Jenis Kelamin

(Nurhasan, 2013:70)

\begin{tabular}{|c|c|c|c|c|}
\hline \multicolumn{2}{|c|}{ Usia $6 \mathrm{~s} / \mathrm{d} 9$ tahun } & \multirow{2}{*}{ nilai } & \multicolumn{2}{|c|}{ Usia $10 \mathrm{~s} / \mathrm{d} 12$ tahun } \\
\cline { 5 - 5 } \cline { 4 - 5 } putra & putri & & putra & Putri \\
\hline $38 \mathrm{~cm}$ ke atas & $38 \mathrm{~cm}$ ke atas & 5 & $46 \mathrm{~cm}$ ke atas & $42 \mathrm{~cm}$ ke atas \\
\hline $30-37 \mathrm{~cm}$ & $30-37 \mathrm{~cm}$ & 4 & $38-45 \mathrm{~cm}$ & $34-41 \mathrm{~cm}$ \\
\hline $22-29 \mathrm{~cm}$ & $22-29 \mathrm{~cm}$ & 3 & $31-37 \mathrm{~cm}$ & $28-33 \mathrm{~cm}$ \\
\hline $13-21 \mathrm{~cm}$ & $13-21 \mathrm{~cm}$ & 2 & $24-30 \mathrm{~cm}$ & $21-27 \mathrm{~cm}$ \\
\hline Di bawah $13 \mathrm{~cm}$ & Di bawah $13 \mathrm{~cm}$ & 1 & Di bawah $24 \mathrm{~cm}$ & Dibawah $21 \mathrm{~cm}$ \\
\hline
\end{tabular}

\begin{tabular}{|c|c|c|c|c|}
\hline Usia $13 \mathrm{~s} / \mathrm{d} 15$ tahun & \multirow{2}{*}{ nilai } & \multicolumn{2}{|c|}{ Usia $16 \mathrm{~s} / \mathrm{d} 19$ tahun } \\
\cline { 5 - 5 } putra & putri & & putra & Putri \\
\hline $66 \mathrm{~cm}$ ke atas & $50 \mathrm{~cm}$ ke atas & 5 & $73 \mathrm{~cm}$ ke atas & $50 \mathrm{~cm}$ ke atas \\
\hline $53-56 \mathrm{~cm}$ & $39-49 \mathrm{~cm}$ & 4 & $60-72 \mathrm{~cm}$ & $39-49 \mathrm{~cm}$ \\
\hline $42-52 \mathrm{~cm}$ & $30-38 \mathrm{~cm}$ & 3 & $50-59 \mathrm{~cm}$ & $31-38 \mathrm{~cm}$ \\
\hline $31-41 \mathrm{~cm}$ & $21-29 \mathrm{~cm}$ & 2 & $39-49 \mathrm{~cm}$ & $23-30 \mathrm{~cm}$ \\
\hline Di bawah $31 \mathrm{~cm}$ & Di bawah $21 \mathrm{~cm}$ & 1 & Di bawah $39 \mathrm{~cm}$ & Dibawah $23 \mathrm{~cm}$ \\
\hline
\end{tabular}

5. Lari jarak sedang

Lari jarak sedang dilakukan untuk mengukur daya tahan paru, jantung, dan pembuluh darah. Jarak yang ditempuh bergantung pada kelompok umur masingmasing. Adapun lari jarak tempuh dapat di lihat pada halaman sebelas

Tabel 5

Jarak Tempuh Lari Berdasarkan Kelompok Umur

\begin{tabular}{|c|c|c|}
\multicolumn{2}{c}{ (Nurhasan, 2013:72) } \\
\cline { 2 - 3 } Kelompok umur & putra & putri \\
\hline \multirow{2}{*}{$6 \mathrm{~s} / \mathrm{d} 9$ tahun } & $600 \mathrm{~m}$ & $600 \mathrm{~m}$ \\
\hline $10 \mathrm{~s} / \mathrm{d} 12$ tahun & $600 \mathrm{~m}$ & $600 \mathrm{~m}$ \\
\hline $13 \mathrm{~s} / \mathrm{d} 15$ tahun & $1000 \mathrm{~m}$ & $800 \mathrm{~m}$ \\
\hline $16 \mathrm{~s} / \mathrm{d} 19$ tahun & $1200 \mathrm{~m}$ & $1200 \mathrm{~m}$ \\
\hline
\end{tabular}


Tabel 5.1

Norma Penilaian Lari Jarak Sedang

(Nurhasan,2013:73)

\begin{tabular}{|c|c|c|c|c|}
\hline \multicolumn{2}{|c|}{ Usia $6 \mathrm{~s} / \mathrm{d} 9$ tahun } & \multirow{2}{*}{ nilai } & \multicolumn{2}{|c|}{ Usia $10 \mathrm{~s} / \mathrm{d} 12$ tahun } \\
\hline putra & putri & & putra & putri \\
\hline Sd 2'39"' & sd 2'53" & 5 & Sd 2'09" & sd 2'32"' \\
\hline 2'40"-3'00" & 2'54"'-3'-23"' & 4 & 2'10"-2'30"' & 2'33"-2'54"' \\
\hline 3’01'-3'45" & 3'24"-4’08' & 3 & 2’31'-2'45"' & 2'55"-3’28" \\
\hline 3'36'-4'48'" & 4'09'-5'03"' & 2 & 2'46"-3’44" & 3'29'-4'22'” \\
\hline Dibawah 4'48" & dibawah 5'03" & 1 & dibawah 3'44"' & dibawah 4'22" \\
\hline
\end{tabular}

\begin{tabular}{|c|c|c|c|c|}
\hline \multicolumn{2}{|c|}{ Usia $13 \mathrm{~s} / \mathrm{d} 15$ tahun } & \multirow{2}{*}{ nilai } & \multicolumn{2}{|c|}{ Usia $16 \mathrm{~s} / \mathrm{d} 19$ tahun } \\
\hline putra & putri & & putra & putri \\
\hline Sd 3'04" & sd 3'08' & 5 & sd 3'14" & sd 3'52' \\
\hline 3'05"-3'53" & 3'07'-3'55" & 4 & 3'15"-4'25" & 3'53"-4'56" \\
\hline 3'54"-4'46" & 3'56"-4'58"' & 3 & 4'26"-5'12" & 4'57'-5'58' \\
\hline 4'47"-6'04"' & 4'59"-6'40" & 2 & 5'13"-6’33" & 5'59'-7'23"' \\
\hline Dibawah 6'04"' & dibawah 6'40" & 1 & dibawah 6'33"' & dibawah 7'23"' \\
\hline
\end{tabular}

Setelah selesai melakukan kegiatan kategori kebugaran kita harus menjumlahkan diskusi mahasiswa melakukan simulasi tes semua nilai dari lima item tes tersebut kebugaran dengan cara sebagian menjadi tester kemudian cocokan dengan tabel enam di bawah dan sebagian menjadi sampel. untuk kreteria ini:

Tabel 6

Norma Tes Kebugaran Jasmani

(Nurhasan,2013:74)

\begin{tabular}{|c|c|c|}
\hline no & Jumlah nilai & klasifikasi \\
\hline 1 & $22-25$ & Baik sekali (BS) \\
\hline 2 & $18-21$ & baik (b) \\
\hline 3 & $14-17$ & sedang (s) \\
\hline 4 & $10-13$ & Kurang (K) \\
\hline 5 & $05-09$ & Kurang sekali (KS) \\
\hline
\end{tabular}

\section{Jurnal Refleksi Edukatika}

Vol. 6 No. 2 Juni 2016 


\section{KESIMPULAN}

Kesegaran Jasmani adalah kondisi jasmani yang bersangkutan dengan kemampuan dan kesanggupannya berfungsi dalam pekerjaan secara optimal dan efisien. Kesegaran Jasmani erat kaitannya dengan kebutuhan hidup manusia untuk bergerak dan melakukan pekerjaan atau kegiatan sehari-hari. Kesegaran jasmani seseorang dapat diketahui dengan melakukan pengukuran dengan instrumen tes/alat, salah satu instrumen yang biasa digunakan untuk mengukur kesegaran jasmani di Indonesia adalah Tes Kesegaran Jasmani Indonesia ( TKJI ). TKJI dibagi dalam 4 kelompok umur, yaitu kelompok umur 6-9 tahun, 10-12 tahun, 13-15 tahun, dan 16-19 tahun. Dalam hal in mahasiswa mampu memaparkan TKJI untuk usia 16-19 tahun yang terdiri dari 5 item tes yaitu tes lari 60 meter, gantung siku 60 detik, baring duduk 60 detik, loncat tegak serta lari 1000 meter untuk putri dan 1200 meter untuk putra. Tes ini merupakan suatu rangkaian tes jadi dalam pelaksanaannya tidak boleh terputus namun berkelanjutan dalam suatu rangkaian tes.

Tes kebugaran jasmani seharusnya dikuasai oleh calon guru SD terkait kurang berminatnya para pengajar lulusan Pendidikan Jasmani untuk mengajar olahraga, dengan terkuasainya rangkaian tes ini, mahasiswa dianggap mampu untuk mengukur tingkat kebugaran jasmani anak. Walaupun sebetulnya untuk mengajar PENJAS masih banyak diperlukan kemampuan atau kompetensi pada penguasaan cabang olahraga yang lain. Akan tetapi tidak menutup kemungkinan apabila telah terkuasainya tes ini maka setidaknya calon pengajar akan percaya diri untuk mengajar PENJAS.

\section{DAFTAR PUSTAKA}

Arikunto, Suharsimi, (2006). Penelitian Tindakan Kelas. Jakarta: Bumi Aksara.

Departemen Pendidikan Nasional, (2006), Bahan Balajar Mandiri Pengelolaan
Kualitas KKG/MGMP, Jakarta: Direktorat Jenderal Peningkatan Mutu Pendidik dan Tenaga Kependidikan dalam

http://www.scribd.com/document_down loads/direct/47279927?extension=pdf\&f $\mathrm{t}=1332620088$

Hamid, M (2014). Indonesia kekurang 54 ribu guru PENJASKES. [Online]. http://www.sekolahdasar.net/2014/10/in donesia-butuh-54-ribu-guru-penjaskesdi-sd.html

Koentjaraningrat, (1994). Metode Penelitian Masyarakat, Jakarta: Raja Grafindo Persada

Nurhasan. (2013). Tes dan Pengukuran Pendidikan Olahraga. FPOK UPI

Rofiq, aunur (2016). Kabupaten Blitar Kekurangan 1000 Lebih Guru Kelas.diakses1maret2016.http://www.ti mesindonesia.co.id/baca/kabubatenblitar

Subroto, B. Suryo, (2002). Proses Belajar Mengajar di Sekolah, Jakarta: Rineka Cipta.

Syaiful Bahri Djamarah. (2000). Prestasi Belajar dan Kompetensi Guru. Surabaya: Usaha Nasional.

Sri Anitah, W. (2007). Microteaching dan Supervisi Klinis. Surakarta: FKIP UNS.

Nurhasan. (2007). Tes dan Pengukuran Pendidikan Olahraga. FPOK UPI

Usman, Moh. Uzer, (2005). Menajadi Guru Profesional, Bandung: PT Remaja Rosda Karya.

Surya, Moh (1988), Dasar- Dasar Konseling Pendidikan (Konsep dan Teori), Yogyakarta: Kota Kembang. 